Bull. Mater. Sci, Vol. 2, Number 3, August 1980, pp. 151-154. (C) Printed in India.

\title{
Separation of rare earths by ion exchange
}

\author{
G S RAO and G M PHATAK \\ Chemistry Division, Bhabha Atomic Research Centre, Trombay, Bombay 400 085, \\ India
}

MS received 3 April 1980

\begin{abstract}
Separation of rare earths from monazite source by ion-exchange process is discussed. Optimum conditions for obtaining kilogram quantities of individual rare earths of high purity are reported.
\end{abstract}

Keywords. Separation; rare earth; ion-exchange ; eluent ; EDTA.

\section{Introduction}

The fact that the rare earths have yet to earn a place as materials of primary technology is generally attributed to the restricted availability of individual rare earths and their compounds in substantial purities and the cost factor involved therein to compete with other industrial materials which have already established their importance in technology. This drawback is mainly due to the fact that the group of rare earths (At. No. 57-71) and yttrium (At. No. 39 which is also included in the group of rare earths) have similar chemical properties and consequently the processes involved for the separation of rare earths are generally complex, slow and associated with unfavourable economic factors.

Of the free world resources of rare earth elements estimated at about ten million tons (as oxides) India contributes nearly one-third ranking next to the USA. The chief source for rare earths in India is the monazite although a few isolated pockets of samarskite are reported.

The ion-exchange process is highly successful for their separation with high yields of pure materials and hence is now universally adopted for this purpose. Though the separation of rare earths by ion-exchange is well-known (Powell et al 1959), detailed data for scaling up the process were not available.

Realising the importance of making available of individual rare earths in the country for research and development towards their application in technology, the Chemistry Division of the Bhabha Atomic Research Centre has carried out extensive development work on the separation of rare earths by ion-exchange process leading to pilot plant scale operations (Bhat et al 1966). 


\section{Process description}

Didymium carbonate produced by Indian Rare Earths from monazite was used as the starting material (composition: $\mathrm{La}_{2} \mathrm{O}_{3} 49 \cdot 2 \%, \mathrm{CeO}_{2} 1 \cdot 1 \%, \mathrm{Nd}_{2} \mathrm{O}_{3} 34 \cdot 5 \%, \mathrm{Pr}_{6} \mathrm{O}_{11}$ $7 \%, \mathrm{Sm}_{2} \mathrm{O}_{3} 6 \%, \mathrm{Gd}, \mathrm{Tb}$, and heavy rare earths $2 \%$ ).

Utilising the large difference in the basicities of lanthanum and other rare earths, the didymium carbonate was further fractionated into lanthanum-rich and neodymium-rich concentrates. This was achieved by passing air-borne ammonia through rare earth chloride solution $\left(10 \mathrm{gpl}\right.$ as $\left.\mathrm{R}_{2} \mathrm{O}_{3}\right)$ at $60^{\circ} \mathrm{C}$ and at a $\mathrm{pH}$ of 7.8 7.9. Praseodymium, neodymium, samarium and gadolinium contents of these fractions were determined by spectrophotometric analysis (Banks and Klingman 1956). Lanthanum content was obtained by difference.

The ion-exchange method of separation of rare-earths consists of in brief, absorbing the mixed rare earths on the top of a cation exchange resin column with a copper cycle and then eluting the rare earths selectively from the resin column with a suitable aminopolycarboxylate solution. In this process the chelating properties of some of the aminopolycarboxylates mainly ethylenediaminetetraacetate are made use of for selective separation of rare earths. One of the most important physical properties of the rare earth ions that has come to the rescue of the chemist is the gradual decrease of crystal/ionic radius from lanthanum to lutetium (1.061 to $0.848 \AA$ ). This property has a great inverse influence on the stabilities of the rare earth chelates mentioned above, with the result that there is an increase in the stability of the complexes from lanthanum to lutetium. $\left(\log _{10} \mathrm{~K}\right.$ values of EDTA complexes vary from lanthanum to lutetium 15.50 to 19.83 (Schwarzenbach et al 1954). The selective absorbability of the rare earth ions, when eluted in the

Table 1. Experimental conditions for optimum separation of rare earths by ion exchange.

\begin{tabular}{ll} 
Loading & $\begin{array}{l}5 \mathrm{~kg} \text { mixed rare earths as } \\
\mathrm{R}_{2} \mathrm{O}_{3} / \mathrm{unit} .\end{array}$ \\
$\begin{array}{l}\text { Total number of units } \\
\text { Cation exchang:r; }\end{array}$ & $\begin{array}{l}\text { Dowex-50 W } \times 8 \\
\text { Zeocarb } 225\end{array}$ \\
Eluting agent & $\begin{array}{l}\text { EDTA }(0 \cdot 015 \mathrm{M}) \\
\text { pH } 8 \cdot 2-8 \cdot 4\end{array}$ \\
Retaining bed & Copper form of resin \\
Linear flow rate & \\
$\begin{array}{l}\text { (a) loading } \\
\text { (b) elution }\end{array}$ & $\begin{array}{l}1 \mathrm{to} 1 \cdot 2 \mathrm{~cm} / \mathrm{min} \\
\text { Columns }\end{array}$ \\
$\begin{array}{ll}\text { Distance of elution in } \\
\text { band lengths }\end{array}$ & $\begin{array}{l}\text { PVC, Glass } \\
\text { Dia. } 6 \cdot 5-15 \mathrm{~cm} .\end{array}$ \\
\hline
\end{tabular}


form any of the chelates mentioned above, depends on the stability of the chelate ; the higher the stability the lesser is the absorption. The sequence of the elution thus follows from lutetium to lanthanum. A better separation and resolutions of individual rare earths is effected when the rare earth chelates are allowed to interact on the resin bed with transition metal ion such as $\mathrm{Cu}^{2+}$, whose stability constant with EDTA is comparatively high $\left(\log _{10} \mathrm{~K}=18 \cdot 8\right)$.

In the present work various parameters such as $\mathrm{pH}$ of the eluent, flow rates for effective loading and elution and distance of elution for obtaining optimum yields of individual rare earths, were studied in detail and are summarised in table 1.

The individual rare earths from the effluent were precipitated as oxalates and converted to oxides by ignition. The purity was ascertained by spectrophotometric and spectrographic analysis and the results are shown in tables 2 and 3.

Table 2. Some typical plant data on the per cent yield of spce. pure and $\mathbf{A}$. $\mathbf{R}$. grade materials obtained on elution through different number of band lengths.

Total loading : $5 \mathrm{~kg}$ of oxide. Starting material : Didymium carbonate

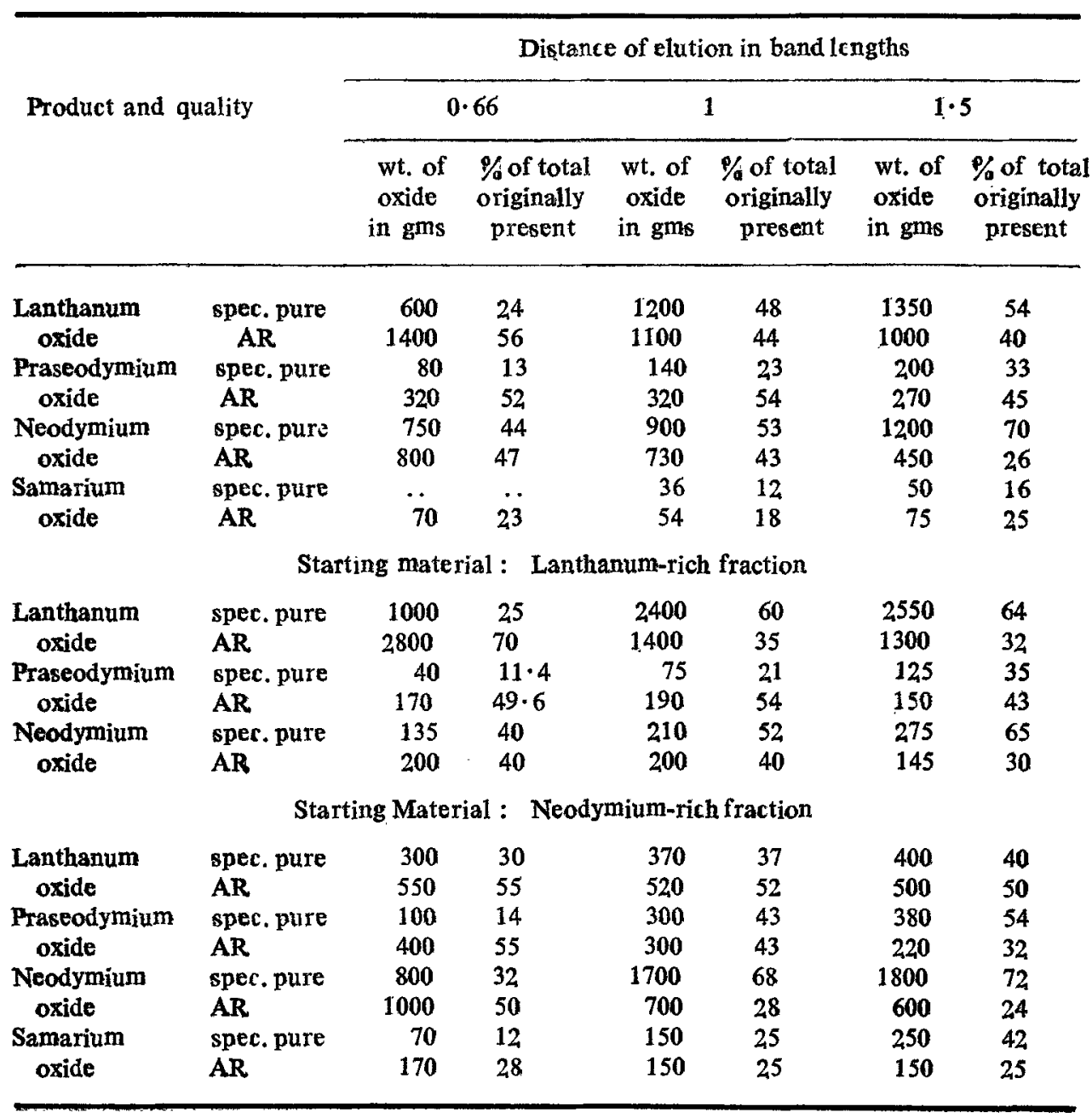


Table 3. Some typical analysis of rare earth oxides produced by ion-exchange separations.

\begin{tabular}{|c|c|c|c|c|}
\hline & \multicolumn{2}{|c|}{ Spec. pure } & \multicolumn{2}{|c|}{ Analytical Grade } \\
\hline Lanthanum oxide & $\begin{array}{l}\mathrm{CeO}_{2} \\
\mathrm{Pr}_{8} \mathrm{O}_{11} \\
\mathrm{Nd}_{2} \mathrm{O}_{8} \\
\mathrm{Fe}\end{array}$ & $\begin{array}{l}<0.01 \% / \\
<0.00 \% \% \\
<0.005 \% \\
0.0008 \%\end{array}$ & $\begin{array}{l}\mathrm{CeO}_{2} \\
\mathrm{Pr}_{6} \mathrm{O}_{11} \\
\mathrm{Nd}_{2} \mathrm{O}_{3} \\
\mathrm{Fe}\end{array}$ & $\begin{array}{l}0.08 \% \\
0.05 \% \\
0.04 \% \\
0.001 \%\end{array}$ \\
\hline $\begin{array}{l}\text { Praseodymium } \\
\text { oxide }\end{array}$ & $\begin{array}{l}\mathrm{La}_{2} \mathrm{O}_{3} \\
\mathrm{CeO}_{2} \\
\mathrm{Nd}_{2} \mathrm{O}_{3} \\
\mathrm{Sm}_{2} \mathrm{O}_{3}\end{array}$ & $\begin{array}{l}<0.01 \% \\
<0.01 \% \\
<0.1 \% \\
<0.01 \%\end{array}$ & $\begin{array}{l}\mathrm{La}_{2} \mathrm{O}_{3} \\
\mathrm{CeO}_{2} \\
\mathrm{Nd}_{2} \mathrm{O}_{3} \\
\mathrm{Fe}\end{array}$ & $\begin{array}{l}0.06 \% \\
0.1 \% \\
0.05 \% \\
0.001 \%\end{array}$ \\
\hline Neodymium oxide & $\begin{array}{l}\operatorname{Pr}_{6} \mathrm{O}_{11} \\
\mathrm{Sm}_{2} \mathrm{O}_{3} \\
\mathrm{Fe}\end{array}$ & $\begin{array}{l}<0.02 \% \\
<0.05 \% \\
<0.0008 \%\end{array}$ & $\begin{array}{l}\mathrm{Pr}_{8} \mathrm{O}_{11} \\
\mathrm{Sm}_{2} \mathrm{O}_{3} \\
\mathrm{Fe}\end{array}$ & $\begin{array}{l}0.08 \% \\
0.08 \% \\
0.00 . \%\end{array}$ \\
\hline Samarium oxide & $\begin{array}{l}\mathrm{Gd}_{2} \mathrm{O}_{3} \\
\mathrm{Nd}_{2} \mathrm{O}_{3} \\
\mathrm{Eu}_{2} \mathrm{O}_{3} \\
\mathrm{Fe}\end{array}$ & $\begin{array}{c}<0.05 \% / \\
<0.025 \% / \\
<0.025 \% \\
0.0008 \%\end{array}$ & $\begin{array}{l}\mathrm{Nd}_{2} \mathrm{O}_{3} \\
\mathrm{Eu}_{2} \mathrm{O}_{3} \\
\mathrm{Gd}_{2} \mathrm{O}_{3} \\
\mathrm{Fe}\end{array}$ & $\begin{array}{l}0.08 \% \\
0.06 \% \\
0.08 \% \\
0.001 \%\end{array}$ \\
\hline Gadolinium oxide & $\begin{array}{l}\mathrm{Eu}_{8} \mathrm{O}_{8} \\
\mathrm{Sm}_{2} \mathrm{O}_{3} \\
\mathrm{~Tb}_{4} \mathrm{O}_{7} \\
\mathrm{Fe}\end{array}$ & $\begin{array}{c}<0.001 \% \\
<0.03 \% \\
<0.05 \% \\
0.0007 \%\end{array}$ & $\begin{array}{l}\mathrm{Sm}_{2} \mathrm{O}_{3} \\
\mathrm{~Tb}_{4} \mathrm{O}_{7} \\
\mathrm{Eu}_{2} \mathrm{O}_{3} \\
\mathrm{Fe}\end{array}$ & $\begin{array}{l}0.08 \% \\
0.05 \% \\
0.1 \% \\
0.00 \%\end{array}$ \\
\hline Yttrium oxide & $\begin{array}{l}\mathrm{Gd}_{2} \mathrm{O}_{3} \\
\mathrm{Dy}_{2} \mathrm{O}_{3} \\
\mathrm{~Tb}_{4} \mathrm{O}_{7} \\
\mathrm{Ho}_{2} \mathrm{O}_{3} \\
\mathrm{~F}_{2}\end{array}$ & $\begin{array}{c}<0.03 \% \\
<0.02 \% \\
<0.025 \% \\
<0.01 \% \\
0.0006 \%\end{array}$ & $\begin{array}{l}\mathrm{Dy}_{2} \mathrm{O}_{3} \\
\mathrm{~Tb}_{4} \mathrm{O}_{7} \\
\mathrm{Fe}\end{array}$ & $\begin{array}{l}0.1 \% \\
0.08 \% \\
0.001 \%\end{array}$ \\
\hline
\end{tabular}

Some typical impurity levels of other elements; $\mathrm{Mg}=0.0006 \% ; \mathrm{Cu}=0.0001 \%$; $\mathrm{Ni}=0.0008 \% ; \quad \mathrm{Ag}=0.0001 \%$.

\section{Conclusion}

Ion-exchange plays an important role in the separation of rare earths. Under optimum conditions of operation it is possible to produce large quantities of high purity rare earths by this technique.

\section{References}

Banks C V and Klingman D W 1956 Anal. Chim. Acta 15356

Bhat T R, Rao T V and Phatak G M 1966 Atomic Energy Establishment, Bombay Tech. Rep. 253

Powell J E and Spedding F H 1959 Trans. Metall. Soc. AIME. 215457

Schwarzenbach G, Gut R and Anderg G 1954 Helv. Chim. Acta 37937 